\title{
Soil biological quality after 36 years of ley-arable cropping, permanent grassland and permanent arable cropping
}

\author{
Nick van Eekeren ${ }^{a, *}$, Lydia Bommelé ${ }^{b}$, Jaap Bloem ${ }^{c}$, Ton Schouten ${ }^{d}$, Michiel Rutgers ${ }^{d}$, \\ Ron de Goede ${ }^{e}$, Dirk Reheul ${ }^{b}$, Lijbert Brussaard ${ }^{e}$ \\ a Louis Bolk Institute, Department of Organic Agriculture, Hoofdstraat 24, NL-3972 LA Driebergen, The Netherlands \\ ${ }^{\mathrm{b}}$ Ghent University, Department of Plant Production, Coupure Links 653, B-9000 Gent, Belgium \\ ${ }^{\mathrm{c}}$ Wageningen University and Research Centre, Alterra, Soil Science Centre, P.O. Box 47, NL-6700 AA Wageningen, The Netherlands \\ ${ }^{\mathrm{d}}$ National Institute for Public Health and the Environment, P.O. Box 1, NL3720 BA Bilthoven, The Netherlands \\ e Wageningen University, Department of Soil Quality, P.O. Box 47, NL-6700 AA Wageningen, The Netherlands
}

\section{A R T I C L E I N F O}

Article history:

Received 27 August 2007

Received in revised form

20 June 2008

Accepted 30 June 2008

Keywords:

Earthworms

Nematodes

Microbiology

Soil biota

Crop rotation

Grassland

\begin{abstract}
A B S T R A C T
Insight is needed into how management influences soil biota when sustainable grassland systems are developed. A crop rotation of grass and maize can be sustainable in terms of efficient nutrient use. However, there is lack of information on the effect of such a crop rotation on soil biological quality. Earthworms, nematodes, bacteria and fungi were sampled over three years in a 36 years old experiment. Permanent arable land was compared with permanent grassland and with a ley-arable crop rotation. In the rotation, a period of three years of grassland (temporary grassland) was followed by a period of three years of arable land (temporary arable land) and vice versa. In the first year of arable cropping in the rotation, the number of earthworms was already low and not different from continuous cropping. In the three-year grass ley, the abundance of earthworms returned to the level of permanent grassland in the second year. However, the restoration of earthworm biomass took a minimum of three years. Furthermore, the anecic species did not recover the dominance they had in the permanent grassland. The numbers of herbivorous and microbivorous nematodes in the ley-crop rotation reached similar levels to those in the permanent treatments within one to two years. Although the same holds for the nematode genera composition, the Maturity Index and the proportion of omnivorous nematodes in the temporary treatments remained significantly lower than in their permanent counterparts. Differences in recovery were also found among microbial parameters. In the temporary treatments, bacterial growth rate and the capacity to degrade a suite of substrates recovered in the second year. However, the Community-Level Physiological Profiles in the permanent grassland remained different from the other treatments. Our results suggest that many functions of soil biota that are well established in permanent grassland, are restored in a ley-arable crop rotation. However, due to a reduction in certain species, specific functions of these soil biota could be reduced or lost. The ley-arable crop rotations were intermediate to permanent grassland and continuous arable land in terms of functioning of soil biota (e.g., Nmineralization). In terms of the functional aspects of the soil biota, permanent grassland might be preferable wherever possible. For maize cultivation, a ley-arable crop rotation is preferable to continuous arable land. However, a ley-arable crop rotation is only preferable to continuous arable cropping if it is not practised at the expense of permanent grassland at farm level.
\end{abstract}

(C) 2008 Elsevier B.V. All rights reserved.

\footnotetext{
* Corresponding author. Tel.: +31 343 523862; fax: +31 343515611.

E-mail address: n.vaneekeren@louisbolk.nl (N. van Eekeren). 
1.

\section{Introduction}

Organic farming and reduced use of external inputs - such as fertilizers and pesticides - in conventional agriculture, implies a greater reliance on ecosystem self-regulating processes (Yeates et al., 1997). Soil biota play an important role in these processes and in the provision of various ecosystem services: supply of nutrients, maintenance of soil structure, water regulation and, more generally, in the resistance and resilience of the below-ground system (Brussaard et al., 1997; Mulder, 2006). Grassland management directly and indirectly influences the soil food web and its functions (Bardgett, 2005). To develop and optimise sustainable grassland systems, insight is needed into how management influences soil biota and how it affects the functioning of the soil-plant system.

On dairy farms in The Netherlands, the main crops are grass (mainly based on Lolium perenne L.) and maize (Zea mays L.). Due to legislative restrictions in The Netherlands, most dairy farms have a maximum of $30 \%$ of their land cultivated with maize. For economic reasons, both crops are mainly continuously cropped, which is only possible thanks to the addition of external inputs. However, recent legislative restrictions on the use of organic and artificial $\mathrm{N}$ fertilizers (Vellinga, 2006) and a quest for sustainable farming systems, have brought attention back to crop rotations with grass and maize. In an experiment with a three year grass and three year maize rotation, Nevens and Reheul (2002) found that maize yield was similar to that in continuous maize cultivation, while the input of $231 \mathrm{~kg}$ of mineral $\mathrm{N}$ fertilizer ha ${ }^{-1}$ was saved over the three-year period of maize in the rotation. In the same experiment the average feed energy yield of grass in the threeyear ley phase was similar to that in permanent grassland (Nevens and Reheul, 2003). Thus, compared to continuous maize cropping and permanent grassland, a crop rotation of grass and maize can be sustainable in terms of efficient nutrient use. Furthermore, ley farming guarantees a high clover content and provides an opportunity to control perennial weeds on organic farms (Younie and Hermansen, 2000). However, farmers lack information on the effect of a leyarable crop rotation on soil quality, especially about soil biological quality, compared with continuous maize cropping and permanent grassland. What are the consequences for soil biological quality at field and farm level if the $30 \%$ of maize now cultivated continuously is cultivated in rotation with grass? Furthermore, what does this mean for the functions of soil biota at field and farm level, in the short and long term?

Permanent grassland and continuous arable cropping represent two types of land use that have distinct effects on biological soil quality. Fromm et al. (1993) showed that the type of cultivation (arable versus pasture) had more influence on soil biota than different soil types. Yeates et al. (1998) and Lamandé et al. (2003) found earthworms to be more abundant and populations to have greater biomass under long-term pasture than under long-term cropping. Similar trends have been found for collembola, nematodes and microbes (Fromm et al., 1993; Yeates et al., 1998; Steenwerth et al., 2002).

Various studies have reported changes in the composition of soil biota on sites with an arable cropping history after which a perennial pasture was established or cultivation was abandoned. Yeates et al. (1998) found that earthworm populations increased when perennial pasture was established on sites formerly under arable cropping. In the case of nematodes, Nombela et al. (1999) detected only a significant difference in the Plant Parasite Index (PPI) during the recovery time after temporary rye cultivation. Buckley and Smidt (2001) found that the soil microbial community structure of an old field, abandoned seven years after cultivation, retained more similarities to cultivated sites nearby than to fields with a similar plant community which had never been cultivated.

None of the above mentioned studies compared a leyarable crop rotation as a cropping system with permanent grass or arable land. In the present research project we analysed the soil biota in a long-term crop rotation experiment established in 1966. Our objectives were (1) to determine the long-term effects of a ley-arable crop rotation system on earthworms, nematodes, bacteria and fungi, in comparison with permanent grassland and continuous arable cropping, and (2) to assess the short-term recovery of soil biota in a leyarable crop rotation. We explored the relevance of changes and/or differences in soil functioning in the short and long term. We hypothesised that three years of grass in a rotation leads to a significant recovery of earthworms, nematodes, bacteria, fungi and mineralization. Furthermore, we hypothesised that, in the long term, the soil biota in a ley-arable crop rotation would reach an intermediate position between permanent grassland and continuous arable cropping.

\section{Materials and methods}

\subsection{Sampling site and experimental design}

In 1966, a crop rotation experiment was established on a sandy loam soil at the experimental farm of Ghent University at Melle $\left(50^{\circ} 59^{\prime} \mathrm{N}, 03^{\circ} 49^{\prime} \mathrm{E} ; 11 \mathrm{~m}\right.$ above sea level). The clay $(<2 \mu \mathrm{m})$, silt $(2-20 \mu \mathrm{m})$, fine sand $(20-200 \mu \mathrm{m})$ and coarse sand $(200-$ $2000 \mu \mathrm{m})$ contents of the soil were $86 \mathrm{~g} \mathrm{~kg}^{-1}, 116 \mathrm{~g} \mathrm{~kg}^{-1}$, $758 \mathrm{~g} \mathrm{~kg}^{-1}$ and $40 \mathrm{~g} \mathrm{~kg}^{-1}$, respectively (Nevens and Reheul, 2001). Four treatments were established in a complete randomised block design with four blocks. The individual plot size was $750 \mathrm{~m}^{2}$. The four treatments were:

PG: Permanent grassland since 1966;

TG: Temporary ley-arable crop rotation, started in 1966 with three years of grass ley followed by three years of arable land cropped with forage crops;

TA: Temporary arable crop-ley rotation. This treatment is comparable to TG but started in 1966 with three years of arable cropping followed by three years of grass ley;

PA: Permanent arable cropping since 1966.

The history of the permanent grassland and the temporary grassland is described in detail in Nevens and Reheul (2003), and the permanent and temporary arable cropping systems in Nevens and Reheul (2001). In the seventh rotation of the trial the TG treatment was established on 12 April 2002 after rotavating the maize stubble of the preceding three years' arable cropping. The seed mixture used was $40 \mathrm{~kg} \mathrm{~L}$. perenne L. $\mathrm{ha}^{-1}$ (cvs. Plenty and Roy) and $4 \mathrm{~kg}$ Trifolium repens L. ha ${ }^{-1}$ (cv. 
Huia). In the seventh rotation the TA treatment was established in 2002 after rotavating the former grass ley on 9 April.

In addition to a nitrogen fertilizer (ammonium nitrate $27 \%$ ), all plots received a basal fertilizer application of triple super phosphate $\left(45 \% \mathrm{P}_{2} \mathrm{O}_{5}\right)$ and potassium chloride $\left(40 \% \mathrm{~K}_{2} \mathrm{O}\right)$. In the spring of 2003 and 2004 treatments were limed. Herbicides were used in the treatments with maize. No pesticides were used on the grassland plots.

\subsection{Soil sampling, chemical and physical measurements}

In the first three years of the seventh rotation, soil samples were collected for soil chemical, physical and biological parameters on 30 October 2002, 7 October 2003 and 15 October 2004. In two of the four blocks with the PG and TG treatments, subplots of $27 \mathrm{~m}^{2}$ with a fertilizer application of $100 \mathrm{~kg}$ mineral $\mathrm{N} \mathrm{ha}^{-1}$ were sampled, while in the other two blocks subplots with $300 \mathrm{~kg}$ mineral $\mathrm{N} \mathrm{ha}^{-1}$ were sampled. In the PA and TA treatments, subplots of $45 \mathrm{~m}^{2}$ with a fertilizer application of $75 \mathrm{~kg}$ mineral $\mathrm{N} \mathrm{ha}^{-1}$ were sampled.

A bulk sample of 70 cores $(0-10 \mathrm{~cm}, \varnothing$ of $2.3 \mathrm{~cm})$ per plot was collected, sieved through $1 \mathrm{~cm}$ mesh, homogenized and stored at field moisture content at $4{ }^{\circ} \mathrm{C}$ before analysis. Subsamples were taken and used for chemical analysis, nematode and microbiological analysis.

Prior to chemical analysis, sub-samples were oven-dried at $40{ }^{\circ} \mathrm{C}$. Soil acidity of the oven-dried samples was measured in $1 \mathrm{M} \mathrm{KCl}$ ( $\mathrm{pH}-\mathrm{KCl})$. Total soil $\mathrm{N}$ was determined by digestion with $\mathrm{H}_{2} \mathrm{SO}_{4}$, salicylic acid, $\mathrm{H}_{2} \mathrm{O}_{2}$ and selenium as described by Novozamsky et al. (1984) and measured by Segmented Flow Analysis (Skalar Breda). Soil organic matter was determined by loss-on-ignition (Ball, 1964).

In 2003 and 2004 soil bulk density was measured in the 5$10 \mathrm{~cm}$ layer below the soil surface, in three undisturbed ring samples containing $100 \mathrm{~cm}^{-3}$ soil. In 2004 , the soil sampling was combined with other measurements on soil structure and physical processes. Penetration resistance was measured with an electronic penetrometer with a cone diameter of $1 \mathrm{~cm}^{2}$ and a $60^{\circ}$ apex angle. Cone resistance was recorded per $\mathrm{cm}$ of soil depth and expressed as an average value of 6 penetrations per plot in the soil layers of $0-10 \mathrm{~cm}, 10-20 \mathrm{~cm}$, etc. Soil structure was determined in 1 block $(20 \mathrm{~cm} \times 20 \mathrm{~cm} \times 10 \mathrm{~cm})$ per plot. Soil of this block was divided by visual observation into crumbs, sub-angular blocky elements and angular blocky elements. These were weighed and expressed as a percentage of total fresh soil weight. On horizontal surfaces $(20 \mathrm{~cm} \times 20 \mathrm{~cm})$ exposed at $10 \mathrm{~cm}$ and $20 \mathrm{~cm}$ depth, the total number of roots was counted and expressed per $\mathrm{m}^{2}$.

\subsection{Soil biological parameters}

\subsubsection{Earthworms}

Earthworms were sampled in 2 blocks $(20 \mathrm{~cm} \times 20 \mathrm{~cm} \times$ $20 \mathrm{~cm}$ ) per plot. The blocks were transferred to the laboratory where the earthworms were hand-sorted, counted, weighed and fixed in alcohol prior to identification. Numbers and biomass were expressed per $\mathrm{m}^{2}$. Adults were identified according to species. A distinction was made between (1) epigeic species (pigmented, living superficially in the litter layer, little burrowing activity), (2) endogeic species (living in burrows at approximately $10-15 \mathrm{~cm}$ depth) and (3) anecic species (relatively large worms, living in vertical burrows from which they collect dead organic matter from the surface at night) (Bouché, 1977). In 2004, before the blocks were sorted, the earthworm burrows with a diameter $>2 \mathrm{~mm}$ were counted on horizontal surfaces $(20 \mathrm{~cm} \times 20 \mathrm{~cm})$ exposed at $10 \mathrm{~cm}$ and $20 \mathrm{~cm}$ depth. The horizontal surface was the same as used for counting the number of roots.

\subsubsection{Nematodes}

From the bulk soil sample a sub-sample of $100 \mathrm{ml}$ soil was taken, from which the free-living nematodes were extracted, using the Oostenbrink elutriator (Oostenbrink, 1960). Total numbers were counted and expressed per $100 \mathrm{~g}$ fresh soil. Nematodes were fixed in hot formaldehyde $4 \%$, and at least 150 randomly selected nematodes from each sample were identified to genus and, whenever possible, to species. Nematode genus and species were assigned to trophic groups following Yeates et al. (1993) and allocated to the colonizerpersister groups (cp-groups) following Bongers (1990) and Bongers et al. (1995). The Nematode Channel Ratio (NCR) was calculated to express the relative contributions of bacterivorous (B) and fungivorous (F) nematodes to the total nematode abundance $(\mathrm{NCR}=\mathrm{B} /(\mathrm{B}+\mathrm{F})$ ) (Yeates, 2003). The Maturity Index is calculated as the weighted mean of the individual cp-values, in accordance with Bongers (1990). It is an ecological measure, which indicates the condition of an ecosystem based on nematode species composition.

\subsubsection{Microbial parameters}

Microbiological analyses were performed in 2003 and 2004. To avoid the effects of temperature and moisture fluctuations in the field and to stabilize soil conditions, a sub-sample of $200 \mathrm{~g}$ field moist soil was adjusted to 50\% WHC (Water Holding Capacity) and pre-incubated at $12{ }^{\circ} \mathrm{C}$ for four weeks (Bloem et al., 2006). After pre-incubation, fungal and bacterial biomass, bacterial growth rate and Community-Level Physiological Profiles (CLPP) were measured. Potential N-mineralization and soil respiration were measured without preincubation because these methods already include soil incubation.

For each sample, $20 \mathrm{~g}$ of soil and $190 \mathrm{ml}$ of demineralized water were homogenized in a blender (Waring, New Hartford, CT) for $1 \mathrm{~min}$ at maximum speed (20,000 rpm). A $9 \mathrm{ml}$ sample was fixed by adding $1 \mathrm{ml}$ of $37 \%$ formaldehyde. The soil suspension was resuspended and after 2 min of settling $10 \mu \mathrm{l}$ of the soil suspension was evenly smeared in a circle of $12 \mathrm{~mm}$ diameter on a printed glass slide (Cel-line Associates Inc., Vineland, NJ, USA). Slides with soil suspension were air-dried (Bloem and Vos, 2004).

Slides for counting of fungi were stained for $1 \mathrm{~h}$ with Differential Fluorescent Stain (DFS) solution. The stain solution consisted of $3.5 \mathrm{~g} \mathrm{l}^{-1}$ europium chelate (Kodak cat no. 1305515, Eastman Fine Chemicals, Rochester, NY, USA) and $50 \mathrm{mg} \mathrm{l}^{-1}$ fluorescent brightener, C40H42N120O10S2Na2 (FW 960.9, Fluostain I, cat no. F0386, Sigma Chemical Co., St. Louis, MD, USA) in $50 \%$ ethanol, filtered through a $0.2 \mu \mathrm{m}$ poresize membrane. Europium chelate stains DNA and RNA red, FB stains cellulose and polysaccharide (cell walls) blue. After 
staining the slides were rinsed three times in a bath of $50 \%$ ethanol. After air-drying a coverslip was mounted with immersion oil.

Fungi were counted under an epifluorescence microscope at $400 \times$ magnification. Blue hyphae are assumed to be inactive or dead, red hyphae are active. Unstained (melanin-forming) hyphae were also counted. Hyphal lengths are estimated by counting the number of intersections of hyphae with the lines of a counting grid. Hyphal length $\left(\mu \mathrm{m}_{\text {grid }}{ }^{-1}\right)$ was calculated as $H=I \pi A / 2 L$, where $I$ is the number of intersections per grid, $A$ is the grid area, $L$ is the total length of lines in the counting grid. The total length of fungal hyphae $F\left(\mathrm{~m} \mathrm{~g}^{-1}\right.$ soil) was calculated as $F=H \times 10^{-6}(A / B)(1 / S)$, where $H$ is the hyphal length, $A$ is the area of the slide covered by sample, $B$ is the area of the grid and $S$ is the amount of soil on the filter. Biovolumes were calculated from length $L$ and width $W$ using the equation $\mathrm{V}=(\pi / 4) \mathrm{W}^{2}(\mathrm{~L}-\mathrm{W} / 3)$. Fungal biomass was calculated assuming a mean hyphal diameter (width) of $2.5 \mu \mathrm{m}$ and a specific

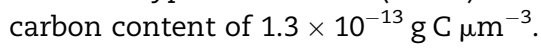

Slides for counting of bacteria were stained for $30 \mathrm{~min}$ with the fluorescent protein dye 5-(4,6-dichlorotriazin-2-yl) aminofluorescein (DTAF). This solution consisted of $2 \mathrm{mg}$ DTAF dissolved in $10 \mathrm{ml}$ buffer solution $\left(0.05 \mathrm{M} \mathrm{Na}_{2} \mathrm{HPO}_{4}\left(7.8 \mathrm{gl}^{-1}\right)\right.$ and $0.85 \% \mathrm{NaCl}\left(8.5 \mathrm{gl}^{-1}\right)$, adjusted to $\left.\mathrm{pH} 9\right)$, filtered through a $0.2 \mu \mathrm{m}$ pore-size membrane. After staining the slides were rinsed three times with buffer. After air-drying a coverslip was mounted with immersion oil (Bloem and Vos, 2004). On the stained slides, bacterial numbers and cell volumes were measured automatically with a confocal laser-scanning microscope (Leica TCS SP2) combined with image analysis software (Leica Qwin pro) as described by (Bloem et al., 1995). Bacterial biomass (C) was estimated from the biovolume using

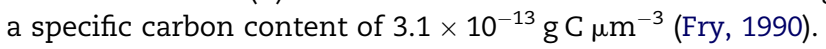

Bacterial growth rate was determined as the incorporation of $\left[{ }^{3} \mathrm{H}\right]$ thymidine and $\left[{ }^{14} \mathrm{C}\right]$ leucine into bacterial DNA and proteins (Bloem and Bolhuis, 2006; Michel and Bloem, 1993). [Methyl- ${ }^{3} \mathrm{H}$ ]thymidine $(925 \mathrm{GBq} / \mathrm{mmol})$ and $\mathrm{L}-\left[\mathrm{U}-{ }^{14} \mathrm{C}\right]$ leucine $(11.5 \mathrm{GBq} / \mathrm{mmol})$ were purchased from Amersham Ltd., Amersham, UK. Per sample (tube) we used $1.5 \mu l\left[{ }^{14} \mathrm{C}\right]$ leucine, $2.0 \mu \mathrm{l}\left[{ }^{3} \mathrm{H}\right]$ thymidine and $16.5 \mu \mathrm{l}$ unlabelled thymidine $(2.35 \mathrm{mg} / \mathrm{l})$. This corresponds with $2 \mu \mathrm{M}$ and $2.78 \mathrm{kBq}\left[{ }^{14} \mathrm{C}\right] \mathrm{leu}-$ cine and $2 \mu \mathrm{M}$ and $74 \mathrm{kBq}\left[{ }^{3} \mathrm{H}\right]$ thymidine per tube. $20 \mathrm{~g}$ soil and $95 \mathrm{ml}$ Prescott and James's mineral salt solution (P\&J medium, Prescott and James, 1955) were shaken by hand in a bottle for $30 \mathrm{~s} .100 \mu \mathrm{l}$ of soil suspension was added to $20 \mu \mathrm{l}$ labelled thymidine and leucine in a $13 \mathrm{ml}$ polypropylene centrifuge tube with screw cap. After 1-h incubation the incorporation was stopped by adding $5 \mathrm{ml}$ of $0.3 \mathrm{~N} \mathrm{NaOH}, 25 \mathrm{mM}$ EDTA and $0.1 \%$ SDS. Blanks were prepared by adding the extraction mixture immediately after the start of the incubation. Macromolecules (DNA and proteins) were extracted at $30^{\circ} \mathrm{C}$ for $18-20 \mathrm{~h}$ (overnight). The suspension was mixed and centrifuged for $40 \mathrm{~min}$ at $5000 \times \mathrm{g}$ at $25^{\circ} \mathrm{C}$ in an MSE High Speed 18 centrifuge. The supernatant was aspired in a $13 \mathrm{ml}$ tube and cooled on ice. After $5 \mathrm{~min} 1.3 \mathrm{ml}$ ice-cold $1 \mathrm{~N} \mathrm{HCl}$ and $1.3 \mathrm{ml}$ ice-cold $29 \%$ TCA (w/v) were added. The suspension was cooled further for at least $15 \mathrm{~min}$. The precipitated macromolecules (DNA and proteins) were collected on a $0.2 \mu \mathrm{m}$ pore size cellulose nitrate filter (BA 83, Schleicher \& Schuell). The filters were washed three times with $5 \mathrm{ml}$ ice-cold $5 \%$ TCA. The filters were transferred to glass scintillation vials and $1 \mathrm{ml}$ $0.1 \mathrm{~N} \mathrm{NaOH}$ and $1 \mathrm{ml}$ ethylacetate were added to dissolve macromolecules and filters. $15 \mathrm{ml}$ Ready Safe scintillation cocktail (Beckman Instruments, Fullerton, CA, U.S.A.) was added and radioactivity was counted in an LKB Wallac 1215 liquid scintillation counter (LKB Instruments, Turku, Finland). Blanks were subtracted and the counted dpm were multiplied by 0.0028378 to calculate pmol thymidine incorporated per gram soil per hour, and by 0.07587 to calculate pmol leucine incorporated per gram soil per hour.

The CLPPs of the bacterial communities in the soil extracts were determined with ECO-plates from BIOLOG Inc. (Hayward, USA). These plates contain a triplicate set of 31 different carbon substrates, a control, a freeze-dried mineral medium and a tetrazolium redox dye. $25 \mathrm{~g}$ of fresh soil, based on its dry weight, was mixed with $250 \mathrm{ml}$ buffer (10 mM BisTris, $\mathrm{pH}$ 7), blended for $1 \mathrm{~min}$ at maximum speed and then centrifuged for $10 \mathrm{~min}$ at $500 \times \mathrm{g}$. The homogeneous supernatant containing extracted bacteria was used for further analysis of CLPPs (Boivin et al., 2006). For each bacterial extract, a dilution series was made using $10 \mathrm{mM}$ BisTris buffer at $\mathrm{pH}$ 7. Each dilution series $\left(3^{-1}\right.$ until $3^{-12}$ ) was used to inoculate four ECO-plates with a volume of $100 \mu \mathrm{l}$ per well. The colour formation in the plate was measured every $8 \mathrm{~h}$ for 7 days with a plate reader spectrophotometer at $590 \mathrm{~nm}$. The CLPPs were calculated from the colour formation in the wells, and corrected for inoculum density using a regression approach applied to the average well colour development (AWCD) as described by Rutgers et al. (2006). This produced CLPPs describing the relative abundance for substrate conversion (31 substrates; log scaled). To survey the bacterial community activity in the ECO-plate, the AWCD was calculated after 7 days of incubation.

Potential N-mineralization was determined by incubating 200 g homogenized and sieved $(<2 \mathrm{~mm})$ soil in 1.5 l airtight jars at $20{ }^{\circ} \mathrm{C}$ and $50 \%$ WHC in the dark for six weeks (Bloem et al., 1994). Results of the first week were not used to avoid effects of soil homogenization. The increase in mineral $\mathrm{N}$ between week 1 and week 6 was used to calculate $\mathrm{N}$-mineralization rates. Sub-samples of $80 \mathrm{~g}$ soil were extracted with $200 \mathrm{ml}$ of $1 \mathrm{M} \mathrm{KCl}$. After $1 \mathrm{~h}$ shaking the extracts were filtered over a paper filter. Mineral $\mathrm{N}$ contents (ammonium and nitrate) were determined by Skalar Segmented Flow Analysis (Breda, The Netherlands). Soil respiration was measured by incubation for seven days at $20{ }^{\circ} \mathrm{C}$ and $50 \%$ WHC. During this period $\mathrm{CO}_{2}$ was absorbed in alkali ( $1 \mathrm{~N} \mathrm{KOH}$ ) followed by titration with $0.1 \mathrm{~N} \mathrm{HCl}$ (Pell et al., 2006).

\subsection{Statistical analyses}

The data were analysed with GENSTAT (8th edition, VSN International, Hemel Hemstaed, UK) using a two-way ANOVA in randomised blocks with treatment ( $\mathrm{PG}, \mathrm{TG}, \mathrm{TA}$ and $\mathrm{PA}$ ), and year of sampling as factors. Where a relationship could be anticipated between parameters, a regression analysis was carried out on a model, in which year and treatment were taken into account where relevant. Data of nematode taxa and CLPPs were squareroot transformed and subjected to a redundancy analysis (RDA) (CANOCO 4.5, Biometris, Wageningen, The Netherlands). In the biplots the 'species' (nematode taxa and bacterial CLPPs) are represented by vectors and the 
treatments (crop, year) by centroids. The length and the slope of the vectors and the position of the centroids indicate the strength of the correlation with the ordination axes and with other variables. Perpendicular projection of a treatment centroid on a 'species' vector indicates the relative abundance of the species in that treatment, with an average abundance at the origin, a higher than average abundance in the direction of the arrow, and a less than average abundance in the opposite direction. A Monte Carlo permutation test (499 random permutations) was performed to test for statistically significant $(P=0.05)$ relationships between community structure and environmental variables following a multivariate analysis of variance design (Van Dobben et al., 1999).

\section{Results}

\subsection{Soil chemical and physical parameters}

The soil organic matter (SOM) in the permanent grassland (PG) plots was almost three times higher than in the permanent arable (PA) plots (Table 1). The crop rotation treatments (TG and TA) had intermediate SOM. The year effect and interaction with treatments was mainly caused by a significant increase of SOM in the PG from 2002 to 2003 and a decrease from 2003 to 2004. The same applies to $\mathrm{N}$-total. The variation in $\mathrm{N}$-total was explained by a regression model $\left(R^{2}=0.94\right)$ with significant effects of treatment $(P<0.001)$, year $(P<0.001)$ and SOM $(\mathrm{P}=0.004)$. The $\mathrm{pH}-\mathrm{KCl}$ was highest in the PA plots and lowest in the TG plots.

PG showed the lowest bulk density while TG and PA showed the highest bulk density. TA bulk density was intermediate (Table 1). When SOM was included in a regression model with treatment, SOM did not significantly $(P=0.160)$ explain the variance in bulk density.
Although the penetration resistance in soil layers below $10 \mathrm{~cm}$ was always lowest in the grass treatments (TG and PG), differences were not statistically significant. Average penetration resistance was $1.56 \mathrm{MPa}$ in $0-10 \mathrm{~cm}, 2.70 \mathrm{MPa}$ in $10-20 \mathrm{~cm}$, 3.42 MPa in 20-30 cm, 3.54 MPa in 30-40 cm and 3.17 MPa in 40$50 \mathrm{~cm}$. The grass treatments had more crumb and sub-angular blocky elements than the arable treatments. Numbers of roots at $10 \mathrm{~cm}$ and $20 \mathrm{~cm}$ were significantly higher in the TG treatment.

\subsection{Soil biological parameters}

\subsubsection{Earthworms}

The number of earthworms was highest in the PG treatment followed by the TG treatment (Table 2). On arable land (TA and PA) the number of earthworms was $12-24 \%$ of the PG. The significant interaction of treatment and year is mainly due to the recovery in the number of earthworms in the TG treatment (Fig. 1). In October 2003, the second year after the establishment of grass (TG) in the arable-ley crop rotation, the number of earthworms reached the same level as in the PG treatment.

The body biomass of the earthworms in the TG was significantly lower $(P<0.001)$ than in the $P G$, and therefore the recovery of the total biomass was not as spectacular as the total numbers. Even in October 2004, the final year of the threeyear period of grass ley, the earthworm biomass in the TG was different from the PG: $96 \mathrm{~g} \mathrm{~m}^{-2}$ compared to $163 \mathrm{~g} \mathrm{~m}^{-2}$ $(P=0.002)$. In total numbers and biomass the TA plots resembled the PA plots. Numbers and especially biomass in the TA treatment had already been at a low level in the first year, suggesting a rapid decrease in earthworms after rotavating the grass ley.

Species of earthworms found in the trial were Lumbricus rubellus, Aporrectodea caliginosa, Allolophora chlorotica, Aporrectodea rosea and Aporrectodea longa. PG had the highest number of

Table 1 - Soil chemical characteristics, physical characteristics and number of roots of permanent grassland (PG), temporary grassland (TG), temporary arable land (TA) and permanent arable land (PA)

\begin{tabular}{|c|c|c|c|c|c|c|c|c|}
\hline \multirow[t]{2}{*}{ Chemical/physical } & \multirow[t]{2}{*}{ Units } & \multicolumn{5}{|c|}{ Treatments } & \multirow{2}{*}{$\begin{array}{c}\text { Year } \\
\text { P-value }\end{array}$} & \multirow{2}{*}{$\begin{array}{c}\text { Treatment } \times \text { year } \\
\text { P-value }\end{array}$} \\
\hline & & PG & TG & TA & PA & P-value & & \\
\hline $\mathrm{SOM}^{\mathrm{a}}$ & g kg dry soil ${ }^{-1}$ & $60.7 \mathrm{a}$ & $33.2 \mathrm{~b}$ & $34.9 \mathrm{~b}$ & $21.1 \mathrm{c}$ & $<0.001$ & 0.004 & 0.003 \\
\hline N-total ${ }^{\mathrm{a}}$ & g N kg dry soil ${ }^{-1}$ & $2.95 \mathrm{a}$ & $1.52 \mathrm{~b}$ & $1.61 \mathrm{~b}$ & $0.95 \mathrm{c}$ & $<0.001$ & $<0.001$ & NS \\
\hline $\mathrm{pH}-\mathrm{KCl}^{\mathrm{a}}$ & & $5.69 \mathrm{c}$ & $5.42 \mathrm{c}$ & $5.83 \mathrm{~b}$ & $6.04 \mathrm{a}$ & $<0.001$ & $<0.001$ & 0.002 \\
\hline Bulk density ${ }^{\mathrm{b}}$ & $\mathrm{g} \mathrm{cm}^{-3}$ & $1.14 \mathrm{c}$ & $1.41 \mathrm{a}$ & $1.29 \mathrm{~b}$ & $1.40 \mathrm{a}$ & $<0.001$ & $<0.001$ & NS \\
\hline \multicolumn{9}{|l|}{ Soil structure $0-10 \mathrm{~cm}^{\mathrm{c}}$} \\
\hline Crumb & $\%$ & $33 a$ & $32 \mathrm{a}$ & $8 b$ & $8 \mathrm{~b}$ & $<0.001$ & - & - \\
\hline Sub-angular & $\%$ & $43 \mathrm{a}$ & $32 \mathrm{a}$ & $11 \mathrm{~b}$ & $12 b$ & $<0.001$ & - & - \\
\hline Angular & $\%$ & $24 b$ & $35 \mathrm{~b}$ & $81 \mathrm{a}$ & 79 a & $<0.001$ & - & - \\
\hline \multicolumn{9}{|l|}{ Roots $^{c}$} \\
\hline $10 \mathrm{~cm}$ depth & $\mathrm{n} \mathrm{m}^{-2}$ & $1888 \mathrm{~b}$ & 3344 a & $906 \mathrm{c}$ & $575 \mathrm{c}$ & $<0.001$ & - & - \\
\hline $20 \mathrm{~cm}$ depth & $\mathrm{n} \mathrm{m}^{-2}$ & $1081 \mathrm{~b}$ & $1813 \mathrm{a}$ & $1269 \mathrm{~b}$ & $963 \mathrm{~b}$ & $<0.008$ & - & - \\
\hline
\end{tabular}

Values followed by the same letter $(a-c)$ within a row are not statistically different at the $5 \%$ error level for the main treatment effect.

a Means of 2002, 2003 and 2004.

b Means of 2003 and 2004.

Measured in 2004 only. 
Table 2 - Earthworm numbers, biomass, species, functional groups and earthworm burrows in permanent grassland (PG), temporary grassland (TG), temporary arable land (TA) and permanent arable land (PA): averages from three consecutive years (2002-2004)

\begin{tabular}{|c|c|c|c|c|c|c|c|c|}
\hline \multirow[t]{2}{*}{ Earthworms } & \multirow[t]{2}{*}{ Units } & \multicolumn{5}{|c|}{ Treatments } & \multirow{2}{*}{$\begin{array}{c}\text { Year } \\
\text { P-value }\end{array}$} & \multirow{2}{*}{$\begin{array}{c}\text { Treatment } \times \text { year } \\
\text { P-value }\end{array}$} \\
\hline & & PG & TG & TA & PA & P-value & & \\
\hline Number of earthworms & $\mathrm{n} \mathrm{m}^{-2}$ & $256 \mathrm{a}$ & $187 \mathrm{~b}$ & $62 c$ & $30 \mathrm{c}$ & $<0.001$ & NS & 0.008 \\
\hline Body biomass & g worm $^{-1}$ & $0.65 \mathrm{a}$ & $0.25 \mathrm{~b}$ & $0.23 \mathrm{~b}$ & $0.12 \mathrm{~b}$ & $<0.001$ & 0.033 & NS \\
\hline Total biomass & $\mathrm{g} \mathrm{m}^{-2}$ & $166 \mathrm{a}$ & $52 \mathrm{~b}$ & $14 \mathrm{bc}$ & $5 \mathrm{c}$ & $<0.001$ & NS & NS \\
\hline Number of species & $\mathrm{n} \mathrm{m}^{-2}$ & $2.0 \mathrm{a}$ & $1.3 \mathrm{~b}$ & $0.5 \mathrm{c}$ & $0.2 \mathrm{c}$ & $<0.001$ & NS & $<0.001$ \\
\hline Epigeic adults & $n m^{-2}$ & $20 \mathrm{a}$ & $25 \mathrm{a}$ & $1 \mathrm{~b}$ & $\mathrm{Ob}$ & 0.016 & 0.011 & NS \\
\hline Endogeic adults & $\mathrm{n} \mathrm{m}^{-2}$ & $46 \mathrm{ab}$ & $49 \mathrm{a}$ & $22 \mathrm{bc}$ & $7 \mathrm{~cd}$ & 0.009 & NS & 0.031 \\
\hline Anecic adults & $\mathrm{n} \mathrm{m}^{-2}$ & $71 \mathrm{a}$ & $4 \mathrm{~b}$ & $2 \mathrm{~b}$ & $0 \mathrm{c}$ & $<0.001$ & NS & NS \\
\hline \multicolumn{9}{|l|}{ Earthworm burrows ${ }^{a}$} \\
\hline $10 \mathrm{~cm}$ depth & $\mathrm{n} \mathrm{m}^{-2}$ & $388 \mathrm{a}$ & $238 \mathrm{~b}$ & $106 \mathrm{c}$ & $6 \mathrm{~d}$ & $<0.001$ & - & - \\
\hline $20 \mathrm{~cm}$ depth & $n m^{-2}$ & $356 \mathrm{a}$ & $206 b$ & $100 \mathrm{c}$ & $6 \mathrm{~d}$ & $<0.001$ & - & - \\
\hline
\end{tabular}

species and the arable treatments the lowest number. The interaction between treatment and year was mainly due to an increase of the number of species in the TG treatment from 2002 to 2003 . As with the total numbers, the number of species in the TG almost recovered within two years in comparison with the PG treatment. Among the adult earthworms in the PG plots, the anecic species were dominant (52\% anecic species). In the TG and the arable treatments (TA and PA), the endogeic species were most common: $62 \%, 88 \%$ and $100 \%$, respectively. The epigeic species were mainly found in the grass treatments.

The number of earthworm burrows showed a clear decrease in the order PG $>$ TG $>$ TA $>$ PA (Table 2). The variation in the number of burrows at $10 \mathrm{~cm}$ depth, measured in October 2004, was explained by a regression model $\left(R^{2}=0.93\right)$ with treatment and earthworm biomass measured in 2004 as fitted terms (Fig. 2). There was a significant positive relation between the biomass and the number of burrows for all treatments (slope $=0.058, P=0.044$ ). In the model all four individual treatment levels differed significantly $(P<0.001)$.

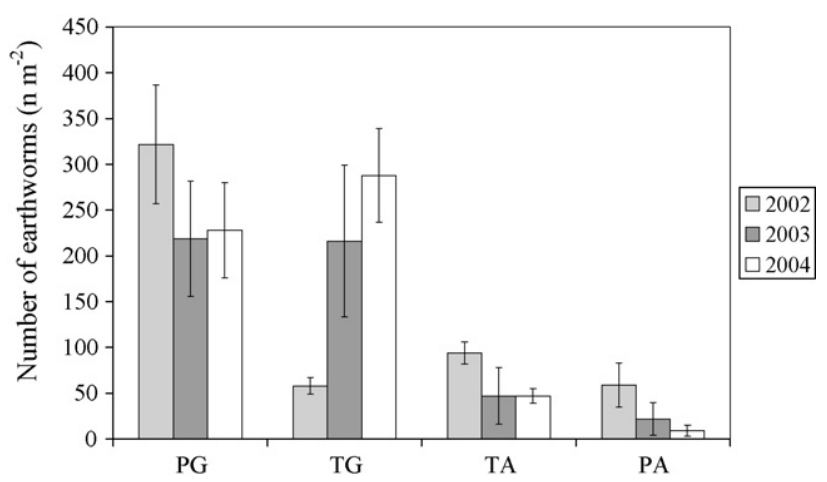

Fig. 1 - Number of earthworms $\left(\mathrm{n} \mathrm{m}^{-2}\right)$ in permanent grassland (PG), temporary grassland (TG), temporary arable land (TA) and permanent arable land (PA): mean values \pm S.E. are shown.

\subsubsection{Nematodes}

The abundance of nematodes in the grassland treatments (PG and TG) and arable treatments (TA and PA) was significantly different over the years (Table 3). The year 2003 showed significantly higher total numbers of nematodes than the years 2002 and 2004. This was mainly caused by higher numbers of nematodes in the PG and TG treatments (Fig. 3). Over the years, nematode numbers were stable in the PA treatment. The interaction between treatment and year resulted from a significant increase in the total number of nematodes in the TG plots and a significant decrease in the TA plots. In 2002, the first year of the 7th rotation in the TG and TA treatments, the number of nematodes was not significantly different between the two treatments: 5007 and 5248 nematodes per $100 \mathrm{~g} \mathrm{soil}^{-1}$, respectively. This could suggest a rapid increase in the number of nematodes after the establishment of the grass and a slow decrease after rotavating the grass. However, changes in trophic groups had already taken place (Fig. 3).

The two grassland treatments (PG and TG) were dominated by herbivorous nematodes. TG showed the highest proportion of herbivores (Table 3 ) and the highest number of roots in the $0-10 \mathrm{~cm}$ soil layer (Table 1). The arable treatments (PA and TA) had the lowest abundance and proportion of herbivorous nematodes and the lowest number of roots in the $0-10 \mathrm{~cm}$ soil layer. The two arable treatments were relatively dominated by bacterivorous nematodes (Table 3). The year effect and interaction for the proportion of bacterivorous and herbivorous nematodes was mainly due to a relative decrease in bacterivores and an increase in herbivores in 2004 in the TA and PA treatments. Moreover, the relative abundance of herbivorous nematodes increased in the years 2003 and 2004 in the TG treatment (Fig. 3). The relative abundance of the fungivorous nematodes did not show statistically significant differences between the treatments (Table 3). However, their absolute numbers were significantly $(P<0.001)$ higher in the grassland plots than in the arable plots. The Nematode Channel Ratio (NCR) suggests that the two arable treatments were dominated to a larger extent by bacterial-based energy channels of decomposition 


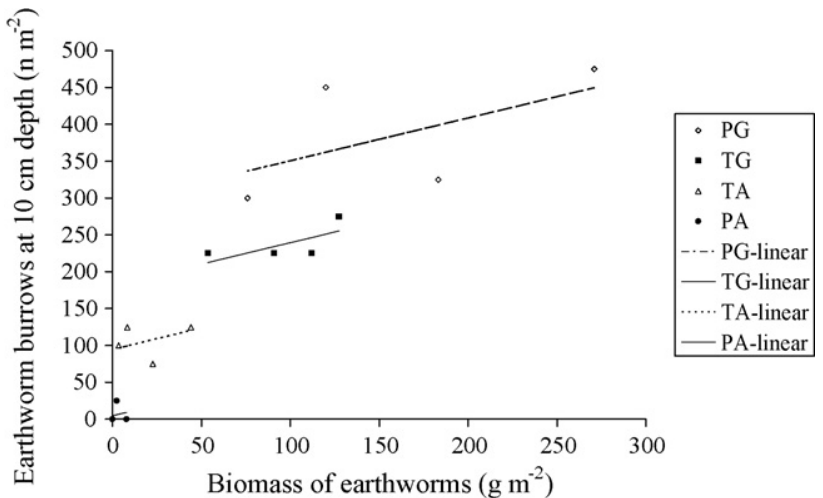

Fig. 2 - Relation between earthworm biomass $\left(\mathrm{g} \mathrm{m}^{-2}\right)$ and earthworm burrows at $10 \mathrm{~cm}$ depth $\left(\mathrm{n} \mathrm{m}^{-2}\right)$ in 2004 for the four treatments $\left(R^{2}=0.93\right)$. Earthworm burrows $\left(\mathrm{n} \mathrm{m}^{-2}\right.$ at $10 \mathrm{~cm}$ depth $)=$ treatment $(\mathrm{P}<0.001)$ (intercept 5 for PA, 95 for TA, 182 for TG, 293 for PG) + $0.58 \times$ earthworm biomass $\left(\mathrm{g} \mathrm{m}^{-2}\right)(\mathrm{P}=\mathbf{0 . 0 4 4 )}$. Permanent grassland $(\mathrm{PG})$, temporary grassland (TG), temporary arable land (TA), permanent arable land (PA).

than the two grassland treatments. The two permanent treatments (PG and PA) showed higher proportions of omnivorous and carnivorous nematodes than the temporary treatments (TG and TA).

The life-strategy group distribution showed a high percentage of $\mathrm{cp}-1$ (enrichment opportunists) in TA. This is mainly due to the dominance of the typical colonizer family

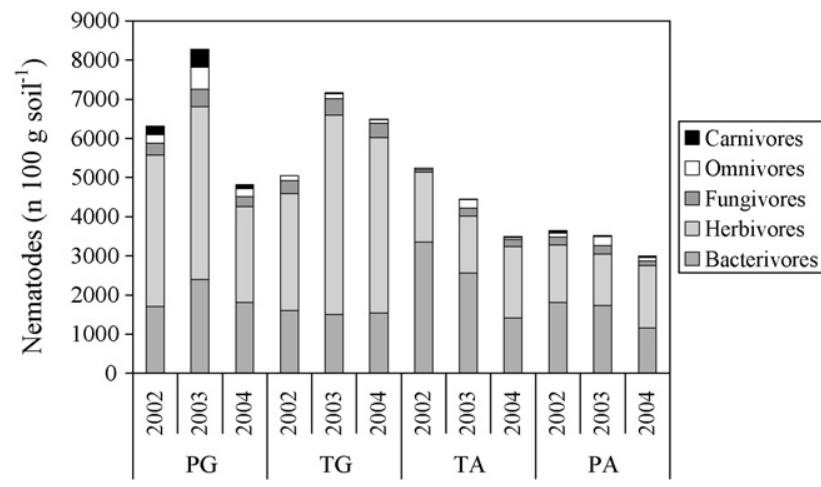

Fig. 3 - Nematode abundance (n $100 \mathrm{~g} \mathrm{soil}^{-1}$ ) divided over the different feeding groups in permanent grassland (PG), temporary grassland (TG), temporary arable land (TA) and permanent arable land (PA).

Rhabditidae in this treatment in the first year after rotavating the three-year temporary grassland. In the second year, species of the bacterivorous Rhabditidae were replaced by the genera Eucephalobus and Acrobeloides of the Cephalobidae family, which are classified as $\mathrm{cp}-2$. The relatively high percentages of omnivorous and carnivorous nematodes in the permanent treatments (PG and PA) resulted in relatively high percentages of cp- 4 and -5 groups. Consequently, the Maturity Index (MI) was highest in PG, followed by PA and TG, and lowest in TA. The MI increased in TA and TG with time. However, the MI of TA in 2004 remained statistically

Table 3 - Nematode abundance, throphic groups, life history groups (cp: colonizer-persister groups) and community structure indices in permanent grassland (PG), temporary grassland (TG), temporary arable land (TA) and permanent arable land (PA): averages from three consecutive years (2002-2004)

\begin{tabular}{|c|c|c|c|c|c|c|c|c|}
\hline \multirow[t]{2}{*}{ Nematodes } & \multirow[t]{2}{*}{ Units } & \multicolumn{5}{|c|}{ Treatments } & \multirow{2}{*}{$\begin{array}{c}\text { Year } \\
\text { P-value }\end{array}$} & \multirow{2}{*}{$\begin{array}{c}\text { Treatment } \times \text { year } \\
\text { P-value }\end{array}$} \\
\hline & & PG & TG & TA & PA & P-value & & \\
\hline Number of nematodes & n $100 \mathrm{~g} \mathrm{soil}^{-1}$ & 6463 a & $6222 \mathrm{a}$ & $4400 \mathrm{~b}$ & $3389 \mathrm{~b}$ & $<0.001$ & 0.002 & 0.004 \\
\hline Bacterivorous & n 100 g soil $^{-1}$ & $1971 \mathrm{~b}$ & $1548 \mathrm{~b}$ & $2445 \mathrm{a}$ & $1571 \mathrm{~b}$ & $<0.001$ & 0.003 & 0.008 \\
\hline Herbivorous & n 100 g soil $^{-1}$ & 3577 a & $4186 \mathrm{a}$ & $1691 \mathrm{~b}$ & $1455 \mathrm{~b}$ & $<0.001$ & NS & 0.003 \\
\hline Fungivorous & n $100 \mathrm{~g} \mathrm{soil}^{-1}$ & $336 \mathrm{a}$ & $378 a$ & $140 \mathrm{~b}$ & $176 \mathrm{~b}$ & $<0.001$ & NS & NS \\
\hline Omnivorous & n 100 g soil $^{-1}$ & $326 a$ & $111 \mathrm{~b}$ & $110 \mathrm{~b}$ & $143 \mathrm{~b}$ & $<0.001$ & $<0.001$ & 0.007 \\
\hline Carnivorous & n 100 g soil $^{-1}$ & 265 & 13 & 14 & 44 & NS & NS & NS \\
\hline Bacterivorous & $\%$ & $31.2 \mathrm{c}$ & $25.6 \mathrm{c}$ & $54.2 \mathrm{a}$ & $46.1 \mathrm{~b}$ & $<0.001$ & 0.014 & 0.002 \\
\hline Herbivorous & $\%$ & $55.2 \mathrm{~b}$ & $66.4 \mathrm{a}$ & $39.7 \mathrm{c}$ & $43.0 \mathrm{c}$ & $<0.001$ & 0.015 & 0.004 \\
\hline Fungivorous & $\%$ & 5.3 & 6.1 & 3.2 & 5.3 & NS & NS & NS \\
\hline Omnivorous & $\%$ & $4.9 \mathrm{a}$ & $2.0 \mathrm{~b}$ & $2.5 \mathrm{~b}$ & $4.2 \mathrm{a}$ & 0.001 & 0.001 & NS \\
\hline Carnivorous & $\%$ & $3.6 \mathrm{a}$ & $0.2 \mathrm{~b}$ & $0.4 \mathrm{~b}$ & $1.3 a b$ & 0.032 & NS & NS \\
\hline $\mathrm{cp}-1$ & $\%$ & $13.8 \mathrm{~b}$ & $18.2 \mathrm{~b}$ & $38.5 \mathrm{a}$ & $15.3 \mathrm{~b}$ & $<0.001$ & $<0.001$ & NS \\
\hline cp-2 & $\%$ & $61.6 \mathrm{bc}$ & $67.8 \mathrm{ab}$ & $54.9 \mathrm{c}$ & $72.3 \mathrm{a}$ & 0.002 & $<0.001$ & NS \\
\hline $\mathrm{cp}-3$ & $\%$ & $3.4 \mathrm{~b}$ & $6.3 \mathrm{a}$ & $0.9 \mathrm{~b}$ & $2.6 \mathrm{~b}$ & 0.003 & NS & 0.020 \\
\hline cp-4 & $\%$ & $10.7 \mathrm{a}$ & $5.6 \mathrm{~b}$ & $4.4 \mathrm{~b}$ & $6.8 \mathrm{~b}$ & 0.010 & 0.049 & NS \\
\hline $\mathrm{cp}-5$ & $\%$ & $10.7 \mathrm{a}$ & $2.2 \mathrm{~b}$ & $1.5 \mathrm{~b}$ & $3.2 \mathrm{~b}$ & 0.010 & NS & NS \\
\hline Number of genera & & 21.6 & 19.4 & 18.4 & 20.3 & NS & $<0.001$ & NS \\
\hline Maturity Index (cp-1-5) & & $2.43 \mathrm{a}$ & $2.06 \mathrm{~b}$ & $1.75 \mathrm{c}$ & $2.11 \mathrm{~b}$ & $<0.001$ & 0.002 & NS \\
\hline Nematode channel ratio & & $0.84 b$ & $0.80 \mathrm{~b}$ & $0.94 \mathrm{a}$ & $0.90 \mathrm{a}$ & $<0.001$ & NS & NS \\
\hline
\end{tabular}

Values followed by the same letter $(a-c)$ within a row are not statistically different at the $5 \%$ error level for the main treatment effect. 


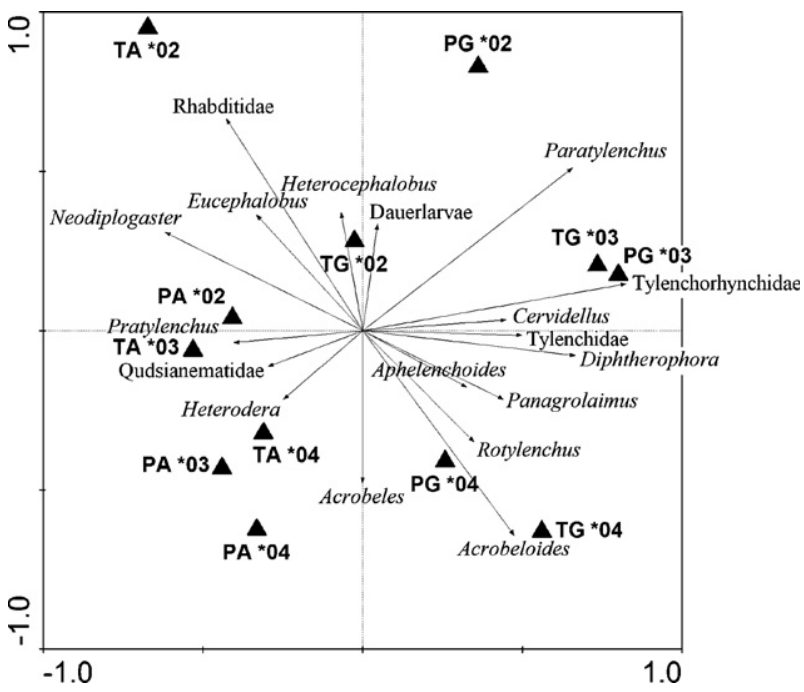

Fig. 4 - Ordination diagram of the nematode taxa based on RDA with treatment (PG, TG, PA, TA) and year (2002, 2003, 2004) accounting for $38 \%$ of the variance in the abundances and $68 \%$ of the variance in the fitted abundances. Only taxa are shown of which $110 \%$ of the variance is accounted for. Permanent grassland (PG), temporary grassland (TG), temporary arable land (TA), permanent arable land (PA).

significantly lower than the MI of PA, whereas the MI of TG in 2004 was not statistically significantly different from the MI of PA.

In a simultaneous multivariate analysis (RDA) of all nematode taxa, statistically significant effects were found for the variables treatment $(P<0.001)$, year $(P<0.001)$ and the interaction year $\times$ treatment $(P<0.001)$. In the ordination plot (Fig. 4) the horizontal axis separates the grassland (right) and the arable (left) treatments, the vertical axis shows the time effect. This again shows that the high numbers of Rhabditidae distinguished the TA treatments in 2002 from the other treatments. In 2002, the first year after rotavation, the TG treatment had an intermediate position between arable and grassland, but from 2003 onwards the temporary treatments resembled their permanent counterparts in terms of nematode taxa. The carnivorous nematodes were not discriminating in the results of this RDA analysis.

\subsubsection{Microbial parameters}

Bacterial biomass was $52 \%$ higher in the PG than in the PA treatment (Table 4). In contrast, the bacterial growth rate (viz. thymidine incorporation or DNA synthesis) was highest in PA and $43 \%$ lower in PG. The bacterial growth rate in the TA treatment did not differ from PA, and the same was found for TG compared to PG. Leucine incorporation (i.e. bacterial protein synthesis) showed similar trends.

Fungal biomass, averaged over the years, also tended to be higher in grassland, but the differences were small (Table 4). The difference was caused by unusual results in 2003 when fungal biomass in the arable fields was as great as or even greater (PA) than in the permanent grassland (PG). The reason is not clear. The difference could not be related to wet or dry conditions. In 2004, a more common result was found with four times less fungal biomass in PA than in PG, and a clear decrease in the order PG $>$ TG $>$ TA $>$ PA. In October 2004, after three years of grass on TG, fungal biomass was significantly higher than after three years of arable farming on TA (data not shown). Fungal activity (percentage of active hyphae) did not show a consistent pattern.

The CLPP-slope parameter (Table 4) was calculated from the colour development in the ECO-plates. This parameter indicates the rate at which the capacity of the soil to degrade a set of carbon and energy substrates disappears upon dilution. A low slope parameter is indicative of a slow disappearance rate and can be considered as a measure of high physiological diversity (Gomez et al., 2004; Rutgers et al., 2006). The PG treatment had the lowest, and the arable treatment the highest slopes (Table 4). This result suggests that the PG

Table 4 - Microbial biomass, activity, Community-Level Physiological Profiles (CLPP), potential N-mineralization and respiration in permanent grassland (PG), temporary grassland (TG), temporary arable land (TA) and permanent arable land (PA): averages from two consecutive years (2003-2004)

\begin{tabular}{|c|c|c|c|c|c|c|c|c|}
\hline \multirow[t]{2}{*}{ Microbial } & \multirow[t]{2}{*}{ Units } & \multicolumn{5}{|c|}{ Treatment } & \multirow{2}{*}{$\begin{array}{c}\text { Year } \\
\text { P-value }\end{array}$} & \multirow{2}{*}{$\begin{array}{c}\text { Treatment } \times \text { year } \\
\text { P-value }\end{array}$} \\
\hline & & PG & TG & TA & PA & $P$-value & & \\
\hline Bacterial biomass & $\mu \mathrm{g}$ C g dry soil ${ }^{-1}$ & $105 \mathrm{a}$ & $78 \mathrm{~b}$ & $82 \mathrm{~b}$ & $69 \mathrm{~b}$ & $<0.001$ & NS & NS \\
\hline Thymidine incorporation & pmol g dry soil ${ }^{-1} \mathrm{~h}^{-1}$ & $23 \mathrm{~b}$ & $26 \mathrm{~b}$ & $36 \mathrm{a}$ & $40 \mathrm{a}$ & $<0.001$ & $<0.001$ & NS \\
\hline Leucine incorporation & pmol g dry soil ${ }^{-1} \mathrm{~h}^{-1}$ & 274 & 336 & 348 & 368 & NS & $<0.001$ & NS \\
\hline Fungal biomass & $\mu \mathrm{g} C \mathrm{~g}$ dry soil ${ }^{-1}$ & 29 & 23 & 18 & 23 & NS & $<0.001$ & 0.021 \\
\hline Fungal activity & $\%$ of hyphal length & 7.7 & 11.0 & 3.6 & 15.1 & NS & 0.004 & 0.046 \\
\hline \multicolumn{9}{|l|}{ CLPP } \\
\hline slope & & $0.26 c$ & $0.50 \mathrm{~b}$ & $0.53 \mathrm{ab}$ & $0.63 a$ & $<0.001$ & NS & NS \\
\hline $\mathrm{ES} 50^{\mathrm{a}}$ & $\mu g$ dry soil & $286 \mathrm{~b}$ & $467 \mathrm{~b}$ & $2391 \mathrm{a}$ & 2811 a & $<0.001$ & NS & NS \\
\hline $\begin{array}{l}\text { Potential } \\
\text { N-mineralization }\end{array}$ & $\begin{array}{l}\text { mg N kg dry } \\
\text { soil }^{-1} \text { week }^{-1}\end{array}$ & $6.8 \mathrm{a}$ & $4.0 \mathrm{~b}$ & $3.2 \mathrm{c}$ & $2.3 \mathrm{~d}$ & $<0.001$ & $<0.001$ & NS \\
\hline Respiration & $\begin{array}{l}\mathrm{mg} \mathrm{CO} 2 \text { kg dry } \\
\text { soil }^{-1} \text { week }^{-1}\end{array}$ & $1356 \mathrm{a}$ & $844 b$ & $639 c$ & $445 d$ & $<0.001$ & 0.008 & NS \\
\hline
\end{tabular}

Values followed by the same letter $(a-d)$ within a row are not statistically different at the $5 \%$ error level for the main treatment effect.

${ }^{a}$ ES50: effective soil needed for $50 \%$ substrate utilization. 


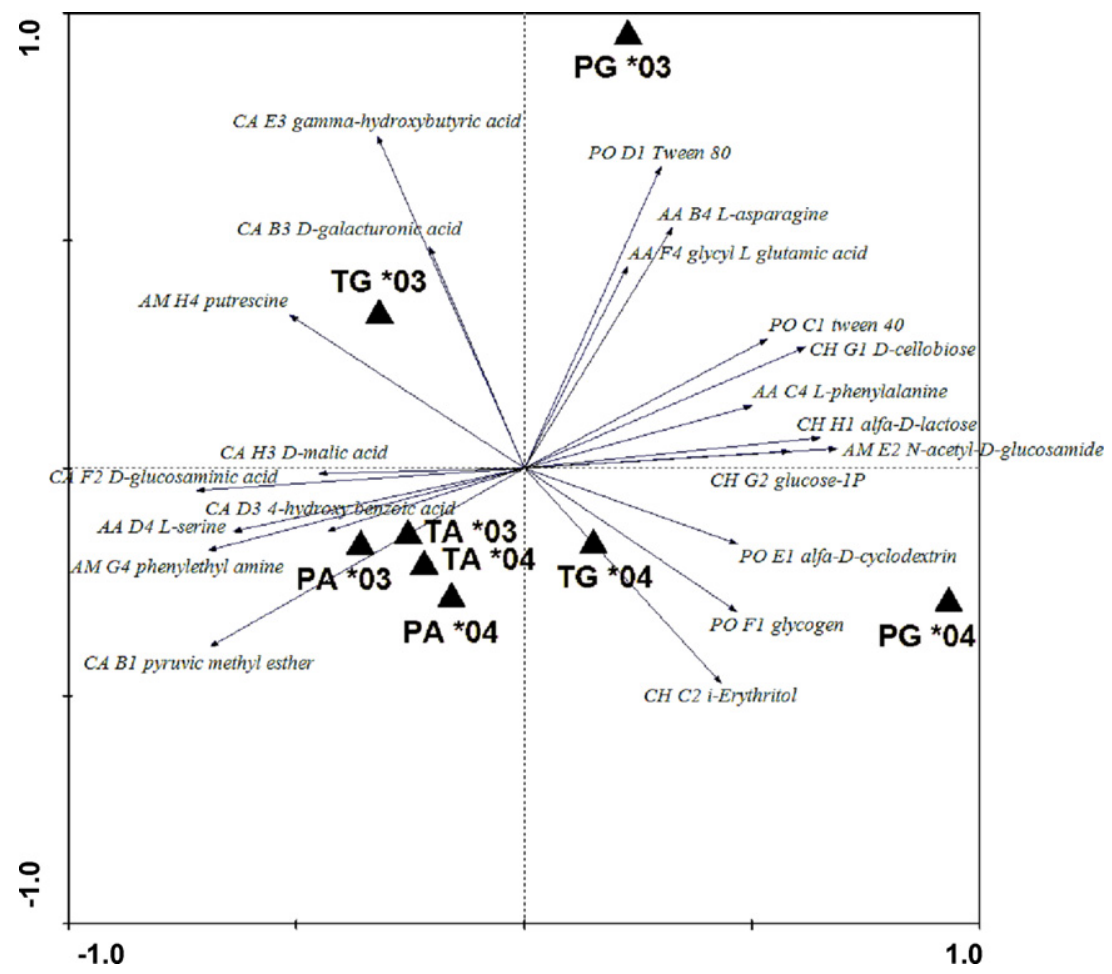

Fig. 5 - Ordination diagram of CLPP's of bacterial communities based on RDA with treatment (PG, TG, PA, TA) and year (2003, 2004) accounting for $30 \%$ of the variance in the abundances and $72 \%$ of the variance in the fitted abundances. Only wells are shown of which $120 \%$ of the variance is accounted for by the diagram (20 out of the total 31 wells). Permanent grassland (PG), temporary grassland (TG), temporary arable land (TA), permanent arable land (PA). Carbohydrate (CH), polymer (PO), amino acid (AA), carboxylic acid (CA), amine (AM).

treatment had a higher physiological diversity than all other treatments, and that the TG treatment had a slightly higher physiological diversity than the continuous arable treatment (PA). In addition, the capacity to degrade a set of different substrates was greatest in the PG and the TG treatments (Table 4), i.e. $<500 \mu \mathrm{g}$ of dry weight (DW) soil was required for $50 \%$ conversion of the different substrates, whereas the arable treatments needed $>2000 \mu \mathrm{g}$ of DW soil.

In a multivariate analysis (RDA) of all CLPPs simultaneously, significant effects were found for treatment $(P<0.001)$, year $(P<.001)$ and the interaction treatment $\times$ year year $(P=0.003)$. In the ordination plot (Fig. 5), the CLPPs of PG are clearly separated from the other treatments in both years and appeared to be different for both years $(P<0.002)$. The CLPPs of TG seemed to be slightly separated from both arable treatments in the multivariate space, but proved only significantly different for the 2003 data $(P=0.010)$. Differences in CLPPs originate from differences in capability of the bacterial communities to degrade a suite of carbon and energy substrates. The PG treatment showed a predominant ability to decompose a distinct set of substrates in the ECO-plates: mainly the carbohydrates, amino acids and polymers, whereas the other treatments (TG, PA, TA) showed a predominant ability to decompose carboxylic acids and amines.

Potential N-mineralization and respiration rates were three times higher in PG than in PA, and decreased significantly in the order $\mathrm{PG}>\mathrm{TG}>\mathrm{TA}>\mathrm{PA}$. Both parameters were higher in
2003 than in 2004, which coincided with the higher SOM and $\mathrm{N}$-total in that year. The variation in respiration was explained by a regression model $\left(R^{2}=0.91\right)$ with significant effects of treatment $(P<0.001)$, year $(P=0.012)$ and SOM $(P=0.048)$. In this model, the intercepts for PA and TA were 0 and -2.3 , respectively, and for PG and TG 22.3 and 18.6, respectively. This model suggests that the respiration of the grassland treatments is higher than that of the arable treatments with the same SOM. Apparently, the SOM of the grassland treatments is of a different quality to that of the arable treatments. In the case of both $\mathrm{N}$-mineralization and respiration, no significant relationship was found with $\mathrm{N}$-total when treatment and year were taken into account.

\section{Discussion}

\subsection{Earthworms}

It is well established that grassland usually contains more earthworms than arable land (Edwards and Bohlen, 1996). In this experiment, the number of earthworms in the PA treatment was as low as $12 \%$ of the number in the PG treatment. Low (1972) reported that after 25 years of regular cultivation, the numbers of earthworms were only $11-16 \%$ of those in old grassland. Edwards and Bohlen (1996) mention two reasons for a decreased number of earthworms, besides the mechanical damage and predation after cultivation, the 
loss of an insulating layer of vegetation and a decreased food supply. The small number of earthworms in the TA treatment, six months after rotavating the grass ley, suggests that the decrease in earthworm numbers in our experiment was rapid. Growing grass over several years favours the growth of earthworm populations and the best way of maintaining a large earthworm population in agricultural land is to include ley farming (Edwards and Bohlen, 1996). In fact, in the ley phase of this experiment, earthworm biomass increased from $8 \mathrm{~g} \mathrm{~m}^{-2}$ in the first year to $51 \mathrm{~g} \mathrm{~m}^{-2}$ in the second year and to $96 \mathrm{~g} \mathrm{~m}^{-2}$ in the third year. This is a biomass increase of 40 $45 \mathrm{~g} \mathrm{~m}^{-2}$ per year. If the grass ley were to last for 4-5 years, similar biomass levels to those in PG could be reached. It has to be noted that due to the plot size, migration of earthworms from other plots or the paths with permanent grassland could have positively affected the results in the TG. However, taking into account the development of the body mass in TG compared to PG, and the dominance of endogeic species in TG versus anecic species in PG, migration from outside our plots did not have a major effect. Another factor which could have played a role in the recovery of the earthworms in the TG treatment was the high proportion of white clover in the TG (28\% of the dry matter production over the years 2002-2004, compared to $5 \%$ of the dry matter production in the PG (unpublished results)). Van Eekeren et al. (2005) have shown that a typical ryegrass clover sward sustains twice as much earthworm biomass than pure ryegrass swards. The effectiveness of using a grass-clover mixture for restoring the earthworm biomass is confirmed by Yeates et al. (1998). In a comparison with a continuous cropping treatment, they measured an earthworm biomass increase of only $13 \mathrm{~g} \mathrm{~m}^{-2}$ biomass after five years perennial ryegrass, whereas there was $113 \mathrm{~g} \mathrm{~m}^{-2}$ increase in a mixture of perennial rye and clover.

It can be concluded that during the three-year grass ley, the abundance and the number of earthworm species can be restored to the level of the PG. However, to restore the earthworm biomass in the crop rotation to the level of the PG treatment, the ley period should be extended. Clover in the grass mixture could help to restore the earthworm biomass. A more lasting difference between the PG treatment and the remaining ley-arable crop rotation treatment is the dominance of the anecic species in the PG.

\subsection{Nematodes}

Nematode abundance was greater in the grassland treatments than in the arable treatments. The Dutch Soil Quality Monitoring Network also found higher numbers of nematodes in pastures than in arable land (Schouten et al., 2004). However, various authors (Freckman and Ettema, 1993; Juma and Mishra, 1988; Sohlenius and Sandor, 1989) showed greater abundance in annual than perennial treatments. Part of this difference could be explained by the sampling date, which fell in October in a ripened maize crop. Boström and Sohlenius (1986) and Juma and Mishra (1988) found a sharper decline in nematode abundance after the harvest of a grain crop than after a perennial crop. In Boström and Sohlenius (1986) the number of herbivorous nematodes followed the development of the root system. The significantly lower number of roots to a depth of $10 \mathrm{~cm}$ in the arable compared to the grassland treatments, combined with less active roots in the ripened maize crop, probably did not provide enough food to sustain high numbers of herbivorous nematodes, and may have influenced the total abundance. In fact, the difference in nematode abundance between the grassland and arable treatments was mainly explained by the difference in abundance of herbivorous nematodes. Both in percentage and in absolute numbers, the grassland treatments were dominated by herbivorous nematodes. Among the PG and TG treatments, the percentage of plant-feeding nematodes was significantly higher in TG, which was the treatment with the highest number of roots in the $0-10 \mathrm{~cm}$ soil layer. Bouwman and Arts (2000) also found a higher number and percentage of herbivorous nematodes in a treatment with a higher grass root density in the upper soil layers.

The nematode community in the arable treatments (TA and PA) was dominated by bacterivorous nematodes. The dominance of bacterivorous nematodes under arable land and herbivores under a perennial crop was also found by Juma and Mishra (1988). In absolute numbers, however, the TA treatment had the highest number of bacterivorous nematodes in the first two years, followed by the PG treatment. In the TA treatment this was caused by the large input of organic matter and the destruction of roots after rotavating the three-year-old grass ley. In the first year, the bacterivorous nematodes in this treatment were mainly Rhabidtitidae, which generally increase following a resource pulse (De Goede et al., 1993; Ettema and Bongers, 1993; Yeates, 2003).

The herbivorous and bacterivorous nematodes in the temporary treatments ( $\mathrm{TG}$ and $\mathrm{TA}$ ) recovered to the levels in the permanent treatments ( $P G$ and $P A$ ) within one to two years. The permanent systems ( $P G$ and $P A$ ) distinguished themselves from the temporary systems (TG and TA) with a higher percentage of carnivorous and omnivorous nematodes. Comparing annual cropping systems with pastures, Wasilewska (1979) found omnivorous and carnivorous nematodes to be the most sensitive trophic groups with respect to tillage. However, in our experiment the continuous cropping with tillage apparently offered a more stable environment than the crop rotation of three-year arable land with three-year grass ley. Yeates et al. (1998), on two soil types, also found the highest number of carnivorous nematodes (mononchids) in soil with a cropping history of either permanent pasture or continuous cropping.

The higher percentage of carnivorous and omnivorous nematodes was reflected in the maturity of the system (Bongers, 1990). The Maturity Index (MI) was highest for the PG and lowest for the TA. The ley-crop rotation only reached the level of maturity of the PA treatment in the third year of the grass leys in the TG. In an investigation into the long-term dynamics of nematode populations, Sohlenius et al. (1987) found a rather stable faunal structure in fields that were continuously cropped with barley. Concerning the difference in maturity between the PG and TG treatment, Wasilewska (1994) found that nematode taxa known to be r-strategists or colonizers dominated in younger meadows while K-strategists or persisters dominated in older meadows. Villenave et al. (2001) showed in their study that the nematode community after 11 years of fallow was still different from that after 21 years of fallow. This clearly shows that it takes more than 
three years before the nematode community in the TG has completely restored to the level of PG. In the present experiment the levels of abundance of herbivorous and microbivorous nematodes in the temporary treatments resembled those of their permanent counterparts within one to two years. While the same holds true for the genera composition, the MI and the proportion of omnivorous nematodes of the temporary treatments remained significantly different to (i.e. lower than) their permanent counterparts.

\subsection{Microbial parameters}

Bacterial biomass was $50 \%$ higher in PG than in PA. In the Dutch Soil Quality Monitoring Network bacterial biomass was also $50-100 \%$ higher in grassland than in arable land (Bloem et al., 2006). Fromm et al. (1993) found a strong correlation between soil carbon content and microbial biomass. Wardle (2002) showed that the ratio of microbial biomass carbon to soil carbon content was different for temperate grassland and temperate arable land. In our experiment the SOM did not significantly explain the variation in bacterial biomass in a regression model in combination with treatment and year. In contrast to the higher biomass in grassland soil, the bacterial growth rate (thymidine incorporation) was lower in grassland than in arable land. At the Wildekamp field in Bennekom, The Netherlands (described by Garbeva et al., 2006), similar results were found in soil from grassland and arable land, stored for six months at $12{ }^{\circ} \mathrm{C}$ (Bloem et al., 2006). In the grassland soil the bacterial biomass remained stable and the growth rate was reduced to almost zero, whereas in the arable soil the bacterial biomass was reduced to almost zero, but the growth rate was stable. The authors concluded that the slow-growing grassland bacteria survived better than the fast-growing arable soil bacteria, and suggested that this may be related to different energetic strategies. Grassland may select for $\mathrm{K}$-strategists (slow-growing bacteria) because it is a more stable environment with a relatively constant food supply from grass roots, whereas arable soils may favour r-strategists (fast-growing colonizers), because substrate inputs are highly seasonal. In the same soils Garbeva et al. (2006) found a higher percentage of K-strategists in the culturable bacterial community from grassland soil, whereas arable soil had a higher percentage of r-strategists. Both cultivation-based and cultivation-independent techniques indicated a higher bacterial diversity in permanent grassland. Grayston et al. (2004) found different microbial community structure in grasslands with different management intensities. Unimproved permanent grassland had the highest microbial biomass and lowest potential activity while the opposite was found in improved (ploughed, re-seeded and fertilized) grassland. Similarly, Haynes (1999) found a higher biomass and a lower metabolic quotient $\left(q \mathrm{CO}_{2}\right.$ or biomass specific respiration) in grassland soil than in arable soil. A high $\mathrm{qCO}_{2}$ indicates low $\mathrm{C}$ substrate use efficiency. The higher specific activity in the arable soil appeared to be mainly due to soil tillage because the $\mathrm{qCO}_{2}$ in cultivated annual grassland was as high as in arable land, whereas in zero-tillage annual grassland the $\mathrm{qCO}_{2}$ was as low as in permanent grassland. The lower specific growth rate (biomass specific thymidine incorporation) in our grassland soils (Table 4) may seem to be in line with a lower specific respiration $\left(\mathrm{qCO}_{2}\right)$ in grassland compared to arable land. However, bacterial growth (biomass production) is not necessarily proportional to respiration, because growth efficiency is not constant. Under nutrient limitation (e.g., substrates with high $\mathrm{C} / \mathrm{N}$ ratio) carbon may be respired away while the bacteria are not able to grow. In our grassland soil (PG) respiration was much higher than in the arable soil (PA), and as a result the (bacterial + fungal biomass) specific respiration was also twice as high as in the grassland soil, suggesting a lower metabolic efficiency (Table 4). This is in contrast with the studies cited above. However, the specific respiration has shown various results. In another study (Haynes and Tregurtha, 1999) increasing periods of intensive cultivation for vegetable production resulted in a linear decline in microbial biomass and basal respiration, but the specific respiration $\left(q \mathrm{CO}_{2}\right)$ was not significantly different between relatively undisturbed, highorganic matter pasture soils and frequently disturbed, loworganic matter arable soils. Such findings confirm those of Wardle and Ghani (1995) who concluded that although cultivation represents a severe disturbance, $q \mathrm{CO}_{2}$ is not predictably enhanced by it.

Since the bacterial growth in the temporary treatments (TG and TA) in the second year of the crop rotation already resembled the bacterial growth of the permanent counterparts (PG and PA), our results suggest that selection for "grassland soil bacteria" and "arable soil bacteria" is a fairly rapid process. This is confirmed by the capacity of the grassland and arable soil to degrade $50 \%$ of the substrates in ECO-plates (Table 4, ES50).

The Community-Level Physiological Profiles (CLPPs) and the slope parameter in samples of the PG treatment suggest a potentially active bacterial community, with a predominant decomposition of carbohydrates, amino acids and polymers. The other treatments showed different CLPPs and slope parameters, indicating lower potential activity, and a predominant decomposition of carboxylic acids and amines. Grayston et al. (2004) observed a predominance of decomposition of some sugars and neutral amino acids in improved grasslands relative to unimproved grasslands and hypothesised an effect of the vegetation on microbial community composition. In our study the predominance of degradation of some sugars and amino acids in grasslands is striking, and corresponded with these observations. The TG treatment showed a slightly different CLPP than the arable treatments, but they still had many characteristics in common. Apparently, three years of grass ley did not restore the CLPP profiles to the level of PG. Similarly, Steenwerth et al. (2002) found distinct differences in PLFA profiles between old permanent pastures and profiles of fallow grasslands. They suggested that the soil environment and the associated microbial community may take decades to recover from cultivation effects. Hatch et al. (2002) showed that the CLPP profiles of a ley already resembled those of arable land in the first year after cultivation.

From our experiment it can be concluded that in the temporary treatments (TG and TA) the bacterial growth rate and the capacity to degrade substrates already resembled those of the permanent counterparts (PG and PA) in the second year of the experiment. However, the CLPP profiles and the 
slope parameter from the ECO-plates showed that the physiological diversity in the permanent grassland remained different from the other treatments.

\subsection{Functional aspects in the short and long term}

Earthworms play a role in the supply of nutrients (e.g., fragmentation and transportation of plant residues and SOM, enhancing microbial activity), soil structure improvement (e.g., creation of biopores, producing excrements, mixing organic and mineral particles) and water infiltration. Examples of effects of earthworms are provided by field experiments in which earthworms were introduced or removed. When Hoogerkamp et al. (1983) introduced earthworms in recently reclaimed polders they found an increase in grass production of $9.7 \%$, as well as an improved physical soil fertility. Clements et al. (1991) found that bulk density increased and the initial infiltration rate decreased after removal of earthworms. In our experiment no relationship could be found between bulk density, soil structure, and earthworms. However, a clear relationship was established between earthworm biomass and the number of earthworm burrows, whereby the number of earthworm burrows was lower in the ley-arable crop rotation than in the PG treatment. The deep, vertical burrows of anecic species can increase water infiltration and root growth, while the shallow burrows of endogeic species generally increase the porosity of the topsoil (Edwards and Shipitalo, 1998). Bouché and Al-Addan (1997) measured an average infiltration rate of $150 \mathrm{~mm} \mathrm{~h}^{-1}$ per $100 \mathrm{~g}$ of earthworms $\mathrm{m}^{-2}$, and more specifically $282 \mathrm{~mm} \mathrm{~h}^{-1}$ per $100 \mathrm{~g} \mathrm{~m}^{-2}$ of anecic species. To restore the functional capacity of earthworms for water infiltration in the ley-arable crop rotation in comparison with the PG treatment, it would be necessary to increase the biomass of earthworms on the one hand and restore the species composition on the other. An increase in biomass could probably be achieved by extending the period of grass ley and including clover in the mixture. A shorter arable period in the crop rotation may help to restore the dominance of anecic species in TG.

Several studies have shown that both herbivorous and microbivorous nematodes can have a profound influence on microbial processes, on available nutrients and on grass growth (Ingham et al., 1985; Bardgett et al., 1999; Ekschmitt et al., 1999). In our experiment the absolute and relative abundance and the genera composition of the herbivorous and microbivorous nematodes in the temporary treatments were the same as in their permanent counterparts within one to two years. In this sense crop rotation has no negative effect on these trophic groups and their functional aspects. However, specifically in the ley-arable crop rotation, we may wonder whether the lower percentage of omnivorous and carnivorous nematodes might affect the functioning of the soil. For example, Bardgett et al. (1999) concluded that the effects of herbivorous and bacterivorous nematodes on nutrient fluxes and grass growth appeared to be strongly influenced by complex interactions between different trophic groups of nematodes and other fauna. Moreover, Wardle et al. (1999) reported significant negative correlations between microbivorous nematodes and predatory nematodes, suggesting top-down regulation in the decomposer foodweb. Our results suggest that these complex interactions between different trophic groups and the possible top-down regulation are not fully restored within a three-year grass ley period as part of a crop rotation.

Bacteria play an important role in nutrient cycling (e.g., catabolize fresh organic matter, mineralize and immobilize nutrients) and soil structure improvement (e.g., soil aggregation through bacterial and fungal compounds). In the treatments with temporary grassland and arable land, bacterial growth rate and the capacity to degrade substrates recovered in the second year to the level of their permanent counterparts. However, the Community-Level Physiological Profiles showed that the physiological diversity in the PG remained different from the other treatments.

Both potential N-mineralization and soil respiration can be seen as a functional output of the soil ecosystem. Potential Nmineralization has been shown to be a good indicator of soil nitrogen availability for plant growth (Curtin et al., 2006). Parfitt et al. (2005) determined relationships between net $\mathrm{N}$ mineralization as a measure of soil biological activity and $\mathrm{N}$ availability in different pasture soils, and explained differences in crop production. In their experiment the potential Nmineralization and soil respiration were three times higher in PG than in continuous cropping. Also Saggar et al. (2001) reported up to five times greater potential $\mathrm{N}$ - and $\mathrm{C}$ mineralization rates in permanent pastures compared to 34 years of arable cropping. In our experiment, TG and TA showed intermediate values of $\mathrm{N}$-mineralization and soil respiration. For soil respiration this pattern was partly accounted for by SOM. Anderson and Domsch (1990) showed that the microbial biomass in crop rotation had a more efficient carbon utilization than the microbial biomass in continuous cropping.

Our results suggest that major functions of the soil biota in PG are restored in a ley-arable crop rotation. However, due to a reduction in certain species groups (anecic earthworms and omnivorous and carnivorous nematodes) in a ley-arable crop rotation, specific functions of these soil biota are reduced or lost. Furthermore, restoration of soil biota and its functions in the ley phase is only temporary, due to the following arable phase of the crop rotation. As a result, a ley-arable crop rotation takes an intermediate position between permanent grassland and continuous arable land in terms of functioning of the soil biota (e.g., N-mineralization). In order to make better use of the functional aspects of the soil biota and to conserve as much biodiversity as possible, permanent grassland might be preferable wherever possible. For maize cultivation, a ley-arable crop rotation is preferable to continuous arable land. However, since $30 \%$ of the land on a dairy farm is generally cultivated with maize, a ley-arable crop rotation is only preferable to continuous arable cropping if it is not practised at the expense of permanent grassland at farm level.

\section{Acknowledgements}

We would like to thank Liesbeth Brands, Riekje Bruinenberg, Jan Bokhorst, Popko Bolhuis, Franciska de Vries, Meint Veninga, An Vos and Marja Wouterse for their assistance 
with soil sampling and the analyses of the different parameters, and Jan-Paul Wagenaar and Frans Smeding for their assistance with data analysis. A framework of different projects and programmes made it possible to carry out these measurements in three consecutive years. We would also like to express our gratitude to the Working Group on Grassland Renewal, the Dutch Soil Quality Monitoring Network, the DWK BO-07-432 Programme on Agrobiodiversity, the Care of Sandy Soils Project and the Soil, Farms and Biodiversity Project.

\section{R E F E R E N C E S}

Anderson, T.H., Domsch, K.H., 1990. Application of ecophysiological quotients $\left(q \mathrm{CO}_{2}\right.$ and $\left.q \mathrm{D}\right)$ on microbial biomass from soils of different cropping histories. Soil Biol. Biochem. 22, 251-255.

Ball, D.F., 1964. Loss-on-ignition as estimate of organic matter + organic carbon in non-calcareous soils. J. Soil Sci. $15,84$.

Bardgett, R.D., 2005. The Biology of Soil: A Community and Ecosystem Approach. Oxford University Press, New York, p. 242.

Bardgett, R.D., Cook, R., Yeates, G.W., Denton, C.S., 1999. The influence of nematodes on below-ground processes in grassland ecosystems. Plant Soil 212, 23-33.

Bloem, J., Vos, A., 2004. Fluorescent staining of microbes for total direct counts. In: Kowalchuk, G.A., De Bruijn, F.J., Head, I.M., Akkermans, A.D.L., Van Elsas, J.D. (Eds.), Molecular Microbial Ecology Manual. 2nd edition. Kluwer Academic Publishers, Dordrecht, pp. 861-874.

Bloem, J., Bolhuis, P.R., 2006. Thymidine and leucine incorporation to assess bacterial growth rate. In: Bloem, J., Hopkins, D.W., Benedetti, A. (Eds.), Microbiological Methods for Assessing Soil Quality. CABI, Wallingford, UK, pp. 23-49.

Bloem, J., Lebbink, G., Zwart, K.B., Bouwman, L.A., Burgers, S.L.G.E., de Vos, J.A., de Ruiter, P.C., 1994. Dynamics of microorganisms, microbivores and nitrogen mineralization in winter wheat fields under conventional and integrated management. Agric. Ecosyst. Environ. 51, 129-143.

Bloem, J., Veninga, M., Shepherd, J., 1995. Fully automatic determination of soil bacterium numbers, cell volumes and frequencies of dividing cells by confocal laser scanning microscopy and image analysis. Appl. Environ. Microb. 61, 926-936.

Bloem, J., Schouten, A.J., Sørensen, S.J., Rutgers, M., van der Werf, A., Breure, A.M., 2006. Monitoring and evaluating soil quality. In: Bloem, J., Hopkins, D.W., Benedetti, A. (Eds.), Microbiological Methods for Assessing Soil Quality. CABI, Wallingford, UK, pp. 23-49.

Bongers, T., 1990. The maturity index: an ecological measure of environmental disturbance based on nematode species composition. Oecologia 83, 14-19.

Bongers, T., De Goede, R.G.M., Korthals, G.W., Yeates, G.W., 1995. Proposed changes of c-p classification for nematodes. Russ. J. Nematol. 3, 61-62.

Boivin, M.E.Y., Greve, G.D., Kools, S.A.E., Van der Wurff, A.W.G., Leeflang, P., Smit, E., Breure, A.M., Rutgers, M., Van Straalen, N.M., 2006. Discriminating between effects of metals and natural variables in terrestrial bacterial communities. Appl. Soil Ecol. 34, 102-113.

Boström, S., Sohlenius, B., 1986. Short-term dynamics of nematode communities in arable soil: Influence of a perennial and an annual cropping system. Pedobiologia 29, 345-357.
Bouché, M.B., 1977. Strategies lombriciennes. In: Lohm, U., Persson, T. (Eds.), Soil Organisms as Components of Ecosystems, vol. 25. Ecological Bulletins, pp. 122-132.

Bouché, M.B., Al-Addan, F., 1997. Earthworms, water infiltration and soil stability: some new assessments. Soil Biol. Biochem. 29, 441-452.

Bouwman, L.A., Arts, W.B.M., 2000. Effects of soil compaction on the relationships between nematodes, grass production and soil physical properties. Appl. Soil Ecol. 14, 213-222.

Brussaard, L., Behan-Pelletier, V.M., Bignell, D.E., Brown, V.K., Didden, W.A.M., Folgarait, P.J., Fragoso, C., Freckman, D.W., Gupta, V.V.S.R., Hattori, T., Hawksworth, D.L., Klopatek, C., Lavelle, P., Walloch, D., Rusek, J., Söderström, B., Tiedje, J.M., Virginia, R.A., 1997. Biodiversity and ecosystem functioning in soil. AMBIO 26, 563-570.

Buckley, D.H., Smidt, T.M., 2001. The structure of microbial communities in soil and the lasting impact of cultivation. Microbial. Ecol. 42, 11-21.

Clements, R.O., Murray, P.J., Sturdy, R.G., 1991. The impact of 20 years' absence of earthworms and three levels of $\mathrm{N}$ fertilizers on a grassland environment. Agric. Ecosyst. Environ. 36, 75-85.

Curtin, D., Wright, C.E., Beare, M.H., McCallum, F.M., 2006. Hot water extractable nitrogen as an indicator of soil nitrogen availability. Soil Sci. Soc. Am. J. 70, 1512-1521.

De Goede, R.G.M., Bongers, T., Ettema, C.H., 1993. Graphical presentation and interpretation of nematode community structure: c-p triangles. Med. Fac. Landbouw Univ. Gent 58/ 2b, 743-750.

Edwards, C.A., Bohlen, P.J., 1996. Biology and Ecology of Earthworms, 3rd edition. Chapman and Hall, London, p. 426.

Edwards, W.M., Shipitalo, M.J., 1998. Consequences of earthworms in agricultural soils: aggregation and porosity. In: Edwards, C.A. (Ed.), Earthworm Ecology. St. Lucie Press, Boca Raton, FL, pp. 147-161.

Ekschmitt, K., Bakonyi, G., Bongers, M., Bongers, M., Boström, S., Dogan, H., Harrison, A., Kallimanis, A., Nagy, P., O'Donnell, A.G., Sohlenius, B., Stamou, G.P., Wolters, V., 1999. Effects of the nematofauna on microbial energy and matter transformation rates in European grassland soils. Plant Soil 212, 45-61.

Ettema, C.H., Bongers, T., 1993. Characterization of nematode colonization and succession in disturbed soil using the maturity index. Biol. Fertil. Soils 16, 79-85.

Freckman, D.W., Ettema, C.H., 1993. Assessing nematode communities in agroecosystems of varying human intervention. Agric. Ecosyst. Environ. 45, 239-261.

Fromm, H., Winter, K., Filser, J., Hantschel, R., Beese, F., 1993. The influence of soil type and cultivation system on the spatial distribution of the soil fauna and micro organisms and their interactions. Geoderma 60, 109-118.

Fry, J.C., 1990. Direct methods and biomass estimation. In: Grigorova, R., Norris, J.R. (Eds.), Methods in Microbiology, vol. 22. Academic Press, London, pp. 41-85.

Garbeva, P., Postma, J., Van Veen, J.A., Van Elsas, J.D., 2006. Effect of above-ground plant species on soil microbial community structure and its impact on suppression of Rhizoctonia solani AG3. Environ. Microbiol. 8, 233-246.

Gomez, E., Garland, J.L., Roberts, M.S., 2004. Microbial structural diversity estimated by dilution-extinction of phenotypic traits and T-RFLP analysis along a land-use intensification gradient. FEMS Microb. Ecol. 49, 253-259.

Grayston, S.J., Campbell, C.D., Bardgett, R.D., Mawdsley, J.L., Clegg, C.D., Ritz, K., Griffiths, B.S., Rodwell, J.S., Edwards, S.J., Davies, W.J., Elston, D.J., Millard, P., 2004. Assessing shift in microbial community structures across a range of grasslands of differing management intensity using CLPP, 
PLFA and community DNA techniques. Appl. Soil Ecol. 25, 63-84.

Hatch, D., Easson, L., Goulding, K., Haygarth, P., Shepherd, M., Watson, C., 2002. Grassland resowing and grass-arable rotations in the United Kingdom: agricultural and environmental issues. In: Conijn, J.G., Velthof, G.L., Taube, F. (Eds.), Grassland Resowing and Grass-arable Crop Rotations. International Workshop on Agricultural and Environmental Issues, Wageningen, The Netherlands, pp. 93-104.

Haynes, R.J., 1999. Size and activity of the soil microbial biomass under grass and arable management. Biol. Fertil. Soils 30, 210-216.

Haynes, R.J., Tregurtha, R., 1999. Effects of increasing periods under intensive arable vegetable production on biological, chemical and physical indices of soil quality. Biol. Fertil. Soils 28, 259-266.

Hoogerkamp, M., Rogaar, H., Eysakkers, H.J.P., 1983. Effects of earthworms on grassland on recently reclaimed polder soils in The Netherlands. In: Satchell, J.E. (Ed.), Earthworm Ecology: From Darwin to Vermiculture. Chapman and Hall, London, pp. 85-105.

Ingham, R.E., Trymow, J.A., Ingham, E.R., Coleman, D.C., 1985. Interactions of bacteria, fungi and their nematode grazers: effects on nutrient cycling and plant growth. Ecol. Monogr. 55, 119-140.

Juma, N.G., Mishra, C.C., 1988. Effect of an annual and a perennial crop on trophic group dynamics of nematodes. Can. J. Soil Sci. 68, 101-109.

Lamandé, M., Hallaire, V., Curmi, P., Pérès, G., Cluzeau, D., 2003. Changes of pore morphology, infiltration and earthworm community in a loamy soil under different agricultural managements. Catena 54, 637-649.

Low, A.J., 1972. The effect of cultivation on the structure and other physical characteristics of grassland and arable soils (1945-1970). J. Soil Sci. 363-380.

Michel, P.H., Bloem, J., 1993. Conversion factors for estimation of cell production rates of soil bacteria from tritiated thymidine and tritiated leucine incorporation. Soil Biol. Biochem. 25, 943-950.

Mulder, C., 2006. Driving force from soil invertebrates to ecosystem functioning: the allometric perspective. Naturwissenschaften 93, 467-479.

Nevens, F., Reheul, D., 2001. Crop rotation versus monoculture: yield, $\mathrm{N}$ yield and ear fraction of silage maize at different levels of mineral $\mathrm{N}$ fertilization. Neth. J. Agric. Sci. 49, 405-425.

Nevens, F., Reheul, D., 2002. The nitrogen- and non-nitrogencontribution effect of ploughed grass leys on the following arable forage crops: determination and optimum use. Eur. J. Agron. 16, 57-74.

Nevens, F., Reheul, D., 2003. Permanent grassland and 3-years leys alternating with 3 years of arable land: 31 years of comparison. Eur. J. Agron. 19, 77-90.

Nombela, G., Navas, A., Bello, A., 1999. Nematodes as bioindicators of dry pasture recovery after temporary rye cultivation. Soil Biol. Biochem. 31, 535-541.

Novozamsky, I., Houba, V.J.G., Temminghoff, E., Van der Lee, J.J., 1984. Determination of total $\mathrm{N}$ and $\mathrm{P}$ in a single soil digest. Neth. J. Agric. Sci. 32, 322-324.

Oostenbrink, M., 1960. Estimating nematode populations by some selected methods. In: Sasser, J., Renkins, W.R. (Eds.), Nematology. Chapel Hill, University of North Carolina Press, pp. 85-102.

Parfitt, R.L., Yeates, G.W., Ross, D.J., Mackay, A.D., Budding, P.J., 2005. Relationships between soil biota, nitrogen and phosphorus availability, and pasture growth under organic and conventional management. Appl. Soil Ecol. 28, $1-13$.
Pell, M., Stenström, J., Granhall, U., 2006. Soil respiration. In: Bloem, J., Hopkins, D.W., Benedetti, A. (Eds.), Microbiological Methods for Assessing Soil Quality. CABI, Wallingford, Oxfordshire, UK, pp. 117-126.

Prescott, D.M., James, T.W., 1955. Culturing of Amoeba proteus on Tetrahymena. Exp. Cell Res. 8, 256-258.

Rutgers, M., Breure, A.M., Insam, H., 2006. Substrate utilization in Biolog (TM) plates for analysis of CLPP. In: Bloem, J., Hopkins, D.W., Benedetti, A. (Eds.), Microbiological Methods for Assessing Soil Quality. CABI, Wallingford, Oxfordshire, UK, pp. 212-227.

Saggar, S., Yeates, G.W., Shepherd, T.G., 2001. Cultivation effect on soil biological properties, microfauna and organic matter dynamics in Eutric Gleysol and Gleyic Luvisol soils in New Zealand. Soil Till. Res. 58, 55-68.

Schouten, T., Breure, A.M., Mulder, C., Rutgers, M., 2004. Nematode diversity in Dutch soils, from Rio to a biological indicator for soil quality. Nematol. Monogr. Perspect. 2, 469-482.

Sohlenius, B., Sandor, A., 1989. Ploughing of a perennial grass ley-effect on the nematode fauna. Pedobiologia 33, 199-210.

Sohlenius, B., Böstrom, S., Sandor, A., 1987. Long-term dynamics of nematode communities in arable soil under four cropping systems. J. Appl. Ecol. 24, 131-144.

Steenwerth, K.L., Jackson, L.E., Cakderón, F.J., Stromberg, M.R., Scow, K.M., 2002. Soil microbial community composition and land use history in cultivated and grassland ecosystems of coastal California. Soil Biol. Biochem. 34, 1599-1611.

Van Dobben, H.F., Ter Braak, C.J.F., Dirkse, G.M., 1999. Undergrowth as a biomonitor for deposition of nitrogen and acidity in pine forest. For. Ecol. Manage. 114, 83-95.

Van Eekeren, N., Smeding, F.W., De Vries F.T., Bloem, J., 2005. Analysis of the soil food web structure under grass and grass-clover. In: Wachendorf, M., Helgadóttir, A., Parente, G. (Eds.), Sward Dynamic, N-flows and Forage Utilisation in Legume-based Systems. Proceedings of the 2nd COST 852 Workshop, Grado, pp. 37-40.

Vellinga, Th.V., 2006. Management and nitrogen utilisation of grassland on intensive dairy farms. Doctorate Thesis. Wageningen University, The Netherlands, $250 \mathrm{pp}$.

Villenave, C., Bongers, T., Ekschmitt, K., Djigal, D., Chotte, J.L., 2001. Changes in nematode communities following cultivation of soils after fallow periods of different length. Appl. Soil Ecol. 17, 43-52.

Wardle, D.A., 2002. Communities and ecosystems: linking the aboveground and belowground components. Monographs in Population Biology 34. Princeton University Press, NJ, $392 \mathrm{pp}$.

Wardle, D.A., Ghani, A., 1995. A critique of the microbial metabolic quotient $\left(q \mathrm{CO}_{2}\right)$ as a bioindicator of disturbance and ecosystem development. Soil Biol. Biochem. 27, 16011610.

Wardle, D.A., Bonner, K.I., Barker, G.M., Yeates, G.W., Nicholson, K.S., Bardgett, R.D., Watson, R.N., Ghani, A., 1999. Plant removals in perennial grassland: vegetation dynamics, decomposers, soil biodiversity and ecosystem properties. Ecol. Monogr. 69 (4), 535-568.

Wasilewska, L., 1979. The structure and function of soil nematode communities in natural ecosystems and agrocenoses. Pol. Ecol. Stud. 5, 97-145.

Wasilewska, L., 1994. The effect of age of meadows on succession and diversity in soil nematode communities. Pedobiologia 38, 1-11.

Yeates, G.W., 2003. Nematodes as soil indicators: function and biodiversity aspects. Biol. Fertil. Soils 37, 199-210.

Yeates, G.W., Shepherd, T.G., Francis, G.S., 1998. Contrasting response to cropping of populations of earthworms and 
predacious nematodes in four soils. Soil Till. Res. 48, 255-264.

Yeates, G.W., Bardgett, R.D., Cook, R., Hobbs, P.J., Bowling, P.J., Potter, J.F., 1997. Faunal and microbial diversity in three Welsh grassland soils under conventional and organic regimes. J. Appl. Ecol. 34, 453-470.

Yeates, G.W., Bongers, T., De Goede, R.G.M., Freckman, D.W., Georgieva, S.S., 1993. Feeding habits in soil nematode families and genera-an outline for soil ecologists. J. Nematol. 25, 315-331.

Younie, D., Hermansen, J., 2000. The role of grassland in organic livestock farming. In: Søegaard, et al. (Eds.), Grassland Farming-Balancing Environmental and Economic Demands. Proceedings of the 18th General Meeting of the European Grassland Federation, Aalborg, Denmark, 22-25 May 2000, pp. 493-509. 